\title{
A Simple Scheme for Modeling Sub-Grid Soil Texture Variability for Use in
}

$$
\text { an Atmospheric Climate Model }
$$

\author{
By Aaron Boone \\ Météo-France/Centre National de Recherche Météorologique, Toulouse, France \\ Peter J. Wetzel \\ NASA Goddard Space Flight Center, Greenbelt, MD, USA
}

(Manuscript received 28 February 1998, in revised form 2 February 1999)

\begin{abstract}
On global atmospheric climate model spatial scales, water budget variables (evapotranspiration, soil moisture and runoff) can vary nonlinearly within a typical grid box primarily due to soil moisture heterogeneity. A good deal of this variability results from subgrid variability of soil texture. For such scales, consideration of the variability of the parameters used to characterize the soil hydrology is warranted. A simple approach, amenable to climate modeling, for characterizing subgrid soil parameter variability is proposed in which several parallel noninteracting soil columns are configured beneath a single soil/vegetation surface. The hydrological parameter mean values and statistical moments, which must be defined for each column, are generated using simple regression relationships which relate the parameters to the grid box mean soil texture (sand and clay composition). This simple approach is used because subgrid heterogeneity parameter data is somewhat limited on a global scale.

The Parameterization for Land-Atmosphere-Cloud Exchange (PLACE) model is used within the Global Soil Wetness Project (GSWP) experimental design to generate global soil moisture fields using the soil heterogeneity model. Grid box average evapotranspiration (used in the solution of the surface energy budget), soil moisture, and runoff represent the three soil columns surface-weighted totals: Results show a profound effect on the primary water budget variables due to consideration of the parameter variability: globally-averaged evapotranspiration is reduced by $17 \%$, and total runoff is increased by $48 \%$ compared to a control run assuming a homogeneous soil texture distribution within each grid box. The global mean runoff ratio is increased by $12 \%$. Soil wetness (SW) increases by $19 \%$, while the soil wetness index (SWI) increases by $49 \%$. It is suggested that future land-surface global data sets contain information regarding subgrid variability of the soil for further testing of methods for modeling sub-grid heterogeneity.
\end{abstract}

\section{Introduction}

Soil Vegetation Atmosphere Transfer Schemes (SVATs) have received an increased amount of attention in recent years due to recognition of the importance of surface characteristics on global climate. SVAT schemes are used to parameterize the exchange of heat, momentum and water between the atmosphere and land surface using a column approach. These columns extend from a reference level in the atmosphere near the surface, down to a specified soil depth. In general, these models attempt to describe key components of the near-surface en-

Corresponding author: Aaron A. Boone, MétéoFrance, CNRM/GMME/MC2, 42 avenue Coriolis, 31057 Toulouse Cedex, France. E-mail: boone@cnrm.meteo.fr (C)1999, Meteorological Society of Japan ergy and hydrologic cycle: transpiration, evaporation from bare soil, precipitation interception, snow accumulation and ablation, infiltration, runoff, soil water storage, and, in some cases, soil ice processes.

Many SVATs have been evaluated through the Project for Inter-comparison of Land-surface $\mathrm{Pa}$ rameterization Schemes (PILPS: Henderson-Sellers et al., 1993; Pitman et al., 1993) for spatial scales from a field $\left(10^{0}\right.$-to $\left.10^{2}-\mathrm{km}^{2}\right)$ (e.g., Chen et al., 1997) up to a river basin comprised of $10^{4}-\mathrm{km}^{2}$ grid boxes (Wood et al., 1998), and for time scales ranging from annual to decadal. Model simulations were performed using specified soil and vegetation parameters and atmospheric forcing. Such forcing consists of precipitation, near-surface humidity, temperature and wind, surface pressure, and downward-directed 
longwave and shortwave radiances. It was shown that variability in the predicted latent and sensible heat fluxes among participant SVATs is on the order of expected climate change.

An important conclusion from PILPS is that soil moisture is one of the most important variables in relation to the partitioning of net radiation into surface fluxes of heat and moisture (Shao and Henderson-Sellers, 1996). Darcy's law is used to model vertical soil water transfer by most SVATs that participated in PILPS, although the implementation varies greatly (Wetzel et al., 1996). The two most common models for calculating the local change in soil water content consist of explicit solution of Richards' equation, and the so-called forcerestore method (Deardorff, 1977), for which transfer coefficients are calibrated based on higher resolution models which use Darcy's law. The importance of the parameterization of the critical link between soil moisture and evapotranspiration and runoff in various PILPS-participant SVATs has been well documented: the interaction between transpiration and soil water content (Mahfouf et al., 1996), the relation between bare-soil evaporation and soil moisture (Desborough et al., 1996), the effect of the distribution of roots in the soil on surface fluxes (Desborough, 1997), and the partitioning of precipitation between runoff and evapotranspiration (Koster and Milly, 1997).

In order to obtain a greater understanding of the role of soil moisture in the surface energy and water budgets on the global scale, soil moisture fields were generated by a number of SVATs used for research and operational numerical weather prediction under the auspices of the Global Soil Wetness Project (GSWP: Dirmeyer, 1997). GSWP is similar to PILPS in that each participant model used specified vegetation and soil parameter values (assigned by GSWP) along with atmospheric forcing needed to drive the schemes (from the ISLSCP Initiative 1 dataset: Meeson et al., 1995: Sellers et al., 1995) for a two-year simulation (1987-1988). One of the main differences between GSWP and PILPS is the larger spatial scale (global) for GSWP.

Soil water transfer (infiltration, runoff, diffusion and drainage), and extraction through evapotranspiration in SVATs, are governed by equations which attempt to characterize the soil through a set of hydrological parameters. Parameters which describe the hydraulic conductivity and soil water potential are nonlinearly related to soil moisture through empirical equations. The formulation by Clapp and Hornberger (1978) (hereafter referred to as the CH78 model) is used by many operational and research SVAT schemes [e.g., OSU (Mahrt and Pan, 1984), SiB (Sellers, et al. 1986), GISS (Abramopoulos, 1988), ISBA (Noilhan and Planton, 1989), BEST (Pitman et al., 1991), CLASS
(Verseghy, 1991), BATS (Dickinson et al., 1993), LSM (Bonan, 1996), PLACE (Wetzel and Boone, 1995), ECMWF (Viterbo and Beljaars, 1995), MOSAIC (Koster and Suarez, 1996), VIC-2L (Liang et al., 1996), LAPS (Mihailovic, 1996), BASE (Desborough, 1998)].

Cosby et al. (1984: hereafter referred to as CEA84) determined expressions for the statistical moments of the soil hydrological parameters for the CH78 model. The variation in particle size distribution, or texture (defined as the normalized sum of the sand, clay and silt fractions), was determined to be the best descriptor of the variability in soil moisture. This simple texture-dependent model is used by many SVATs (including most of those above) to calculate surface and subsurface liquid water and heat transfers, for soil depths typically to several meters deep. The incorporation of more sophisticated soil schemes into numerical weather prediction or atmospheric climate models is hindered by the large number of parameters which must be specified for vast domains.

In general, SVATs use the mean values of these hydrological parameters to represent values over rather large domains (as is the case for GSWP). Although the mean values represent reasonable approximations at small scales, consideration of their variability the climate model scale is warranted. This study proposes the use of atmospheric global climate models, which is conceptually simple and whose parameters can be defined using the limited data available by GSWP (at a global scale). This is then incorporated into the Parameterization for Land-Atmosphere-Cloud Exchange (PLACE) model, (Wetzel and Boone, 1995) to show the influence of subgrid variability of the soil hydrological parameters on a simulated global water budget, using the GSWP experimental design.

\section{Sub-grid soil heterogeneity parameteriza- tion}

At spatial scales considered by climate models (approximately $10^{4}-\mathrm{km}^{2}$ ), it is known that surface fluxes can vary nonlinearly primarily due to subgrid variations in soil, and vegetation properties and precipitation. To combat this problem, many SVAT schemes use various methods for modeling subgrid heterogeneity of the land surface, which have been well documented (see the next section for a brief overview). Modeling approaches to sub-grid variability of the vegetation and soil parameters can be broadly classified into two categories: explicit and statistical. However, defining the needed parameters or statistical moments on a global scale can prove difficult. In the current study, a relatively simple statistical approach is used. The emphasis is on the link between soil moisture, runoff and evapotranspiration. Other processes, such as radiative effects and 
sensible heat flux, are treated in the usual fashion - as grid-box averages. The relevant soil hydrological parameters/statistical moments are derived using the information provided by GSWP, and the limited global data is used to maximum advantage.

\subsection{Overview}

An explicit approach to modeling heterogeneity of the land surface consists of dividing the grid cell into a number of smaller scale patches, characterized by differing soil and vegetation parameters. The point equations describing the evolution of the surface energy and water balances are then applied in each of these sub-domains, resulting in a separate energy and water budget for each patch. The surface-area weighted grid box average fluxes then interact with a single grid box mean atmosphere. Some examples of this approach have been demonstrated: Avissar and Pielke (1989), Koster and Suarez (1992), Pielke et al. (1991), Klaassen (1992), Chen and Avissar (1994), Seth et al. (1994), Clark and Arritt (1995), and Gao (1995). The two main difficulties in applying this method in a global climate model are: (1) computational expense as a distinct surface energy balance must be solved for each patch within each grid box, and (2) the large number of parameters which must be specified for each subdomain within each grid box.

A statistical method for modeling surface heterogeneity consists of applying probability distribution functions to the variables of the point equations. An analytical approach has been applied to equations describing soil water flow, evapotranspiration efficiency and runoff by Entekhabi and Eagleson (1989). A numerical integration is used by Wetzel and Chang (1988), so that different distribution functions can be used. Both of these methods explicitly treat sub-grid heterogeneity of soil moisture. In order to use such an approach, measures of the relevant statistical moments are needed which can be calculated from observed data.

In contrast to purely statistical methods for modeling sub-grid soil moisture variability, there are parameterizations in which this variability is a function of soil properties and topography. Essentially, lowland areas of a grid box are assumed to be more wet than neighboring upland regions due to a closer proximity to the local water table. The model parameters can be calculated (or calibrated) using topographical and/or river catchment data. They are used to define the statistical distribution of soil moisture, and therefore sub-grid runoff. Examples of this so-called contributing area approach have been presented by Quinn and Beven (1993) and Famiglietti and Wood (1994). Such schemes have been incorporated into SVATs for improved hydrology in climate models (Dümenil and Todini, 1992; Stieglitz et al., 1997; Douville, 1998).

\subsection{Proposed model and parameter determination}

In the current study, the soil is divided up into parallel soil columns which interact with the same surface biomass/litter layer. This is an important simplification with respect to standard mosaic approaches, because only a single surface energy budget is used. Each column is assigned a distinct set of soil hydrological parameters, determined either from measurements or statistical relationships. The fact that only soil parameters vary within each grid box isolates the effect of soil parameter or texture variability on the critical interactions between evapotranspiration, runoff, and soil moisture.

The relationships for soil potential and hydraulic conductivity given by the $\mathrm{CH} 78$ model are

$$
\begin{aligned}
& \psi=\psi_{s}\left(\frac{\Theta}{\Theta_{s}}\right)^{-b} \\
& k=k_{s}\left(\frac{\Theta}{\Theta_{s}}\right)^{2 b+3}
\end{aligned}
$$

where $\psi_{s}$ represents the soil water potential at saturation $(\mathrm{m}), k_{s}$ is the saturated hydraulic conductivity $\left(\mathrm{m} \mathrm{s}^{-1}\right), b$ is the retention curve slope, and $\Theta_{s}$ represents the soil porosity $\left(\mathrm{m}^{3} \mathrm{~m}^{-3}\right)$. The volumetric water content is given by $\Theta\left(\mathrm{m}^{3} \mathrm{~m}^{-3}\right)$. Most SVATs use Darcy's law either explicitly or implicitly to govern vertical soil water transfer, so that for a vertically homogeneous soil profile (assumed for the current study by GSWP) these four parameters are all that is required to describe the soil hydrological characteristics.

A well-known problem associated with the CH78 soil hydrological parameter model is that on climate model horizontal spatial scales, such as the $1 \times 1$ degree scale used in the current study, it is very possible that several texture classes (sets of hydrological parameters) coexist within a grid box. As discussed in Kabat et al. (1997), the use of the CH78 model to evaluate vertical flow via Darcy's law is, in general, reasonable at relatively small scales. But application of these parameters using their mean values at the spatial scales considered in this study, is generally not a good approximation. As a result, consideration of parameter variability is warranted.

The GSWP specified five distinct soil textural classes. The corresponding parameters were determined using the average parameters from CEA84 for each of these textures (Table 1). Soil texture class is defined from CEA84 based on the percentage composition of clay, sand, and silt. The basic premise of CEA84 is that meaningful predictive statistical relationships can be developed in order to calculate the mean and statistical moments of the soil parameters to within a good approximation, based on texture alone. The CEA84 model can be written as

$$
g_{m}=\beta_{0, m}+\sum_{n=1}^{3} \beta_{n, m} \chi_{n} \quad(m=1,4)
$$


Table 1. The soil parameters for GSWP together with the corresponding clay and sand fractions (texture) from Cosby et al. (1984).

\begin{tabular}{ccccccc}
\hline $\begin{array}{c}\text { GSWP } \\
\text { class }\end{array}$ & $b$ & $\begin{array}{c}k_{s} \\
\left(10^{-6} \mathrm{~m} / \mathrm{s}\right)\end{array}$ & $\begin{array}{c}\psi_{s} \\
(\mathrm{~m})\end{array}$ & $\begin{array}{c}\Theta_{s} \\
\left(\mathrm{~m}^{3} / \mathrm{m}^{3}\right)\end{array}$ & $\begin{array}{c}\text { sand } \\
\%\end{array}$ & $\begin{array}{c}\text { clay } \\
\%\end{array}$ \\
\hline 1 & 4.26 & 14.11 & -0.0363 & 0.421 & 82 & 6 \\
2 & 4.74 & 5.22 & -0.1413 & 0.434 & 58 & 10 \\
$3(7)$ & 5.25 & 3.39 & -0.3548 & 0.439 & 43 & 18 \\
4 & 6.77 & 4.44 & -0.1349 & 0.404 & 58 & 27 \\
5 & 8.17 & 2.44 & -0.2630 & 0.465 & 32 & 34 \\
\hline
\end{tabular}

$$
\begin{aligned}
\sigma_{m} & =\gamma_{0, m}+\sum_{n=1}^{3} \gamma_{n, m} \chi_{n} \quad(m=1,4), \\
\sum_{n=1}^{3} \chi_{n} & =100 \% .
\end{aligned}
$$

The subscript $m$ represents the index for the parameters (up to four). The parameters $b, \Theta_{s}, \log _{10}\left(\psi_{s}\right)$ and $\log _{10}\left(k_{s}\right)$ are represented by $g_{m}$. The corresponding standard deviations are given by $\sigma_{m} . \chi_{n}$ represents either the clay, silt or sand fraction (\%) depending on the value of the subscript $n$. The linear multivariate regression coefficients used to estimate the mean, and one standard deviation about the mean from CEA84, are denoted by $\beta_{n, m}$ and $\gamma_{n, m}$, respectively. The soil parameter mean values, and those corresponding to \pm one standard deviation calculated from Eq. (2), for each of the five GSWP soil classes are shown in Table 2. They are compared graphically to the mean parameter values from CEA84 (specified by GSWP) in Fig. 1.

The saturated hydraulic conductivity varies by approximately an order of magnitude from \pm one standard deviation (Table 2), for each of the five soil classes. This is important for many SVATs as most models parameterize drainage as being equivalent to the hydraulic conductivity as a lower boundary condition. This drainage can constitute a significant portion of the total model runoff or discharge. The other parameters also have large variations over \pm one standard deviation, to the extent that they overlap across the textural classes. This results in a large variation in the soil hydraulic properties calculated using the CH78 model (Eqs. [1a] and [1b]).

The final step is to determine the relative contribution (weight) of each of the soil columns to the overall grid-box mean soil column. The soil parameters $\left(g_{m}\right)$ were found to be approximately normally distributed over the soil samples used to derive the regression model values (CEA84), so they are assumed to be normally distributed within each grid box for the current study. The largest weight is given to the column representing the mean soil properties for a given grid box, with increasingly lower weights being assigned to the columns approaching \pm one standard deviation. Obviously, observed variations in soil texture within each grid box could be used with Eq. (2) to obtain a more realistic set of parameters, but this data is not available in the current GSWP framework.

\section{Incorporation into PLACE}

PLACE consists of several process models that include a bulk atmospheric boundary layer (ABL), radiative transfer model, nonprecipitating boundary layer cloud option, and a land surface parameterization (Wetzel and Boone, 1995). Only the landsurface component of PLACE is used for the current study as the atmospheric forcing is prescribed for the GSWP. In brief, the land-surface module of PLACE has a single equation for the surface energy balance, equations describing the evolution of the intercepted water and snowpack, a diffusion relation for subsurface soil temperature, a plant internal store for moisture, and rate equations for five soil moisture reservoirs. Only the equations relevant to the study of the effect of soil parameter variability, on the water budget are discussed in this paper, so the reader is referred to Wetzel and Boone (1995) for additional model details.

\subsection{Basic model equations}

The surface energy budget equation is written as

$$
b_{m} \frac{\partial T_{s}}{\partial t}=R_{n}-E-H-G-S_{m}
$$

where $T_{s}$ represents the grid-box mean surface temperature, $b_{m}$ is the effective heat capacity of the surface biomass and litter layer, and $R_{n}, H$, and $G$ represent the grid-box mean net radiation, sensible and ground heat fluxes, respectively. The quantity $S_{m}$ is calculated as a residual, when there is energy available at the surface for snow melt. The grid box mean evapotranspiration (latent heat flux) is given as

$E=(1-\mathrm{F}) E_{D}+\mathrm{F} \sum_{j=1}^{N_{c}} \alpha_{j}\left[\phi E_{V j}+(1-\phi) E_{B j}\right],(4)$

where $E_{D}$ is the evaporation from the precipitation interception store, $\mathrm{F}$ is the dew-free fraction of the 
$\longrightarrow$ avg

$+1 \mathrm{std}$

$\diamond \diamond-1$ std

*-- * GSWP
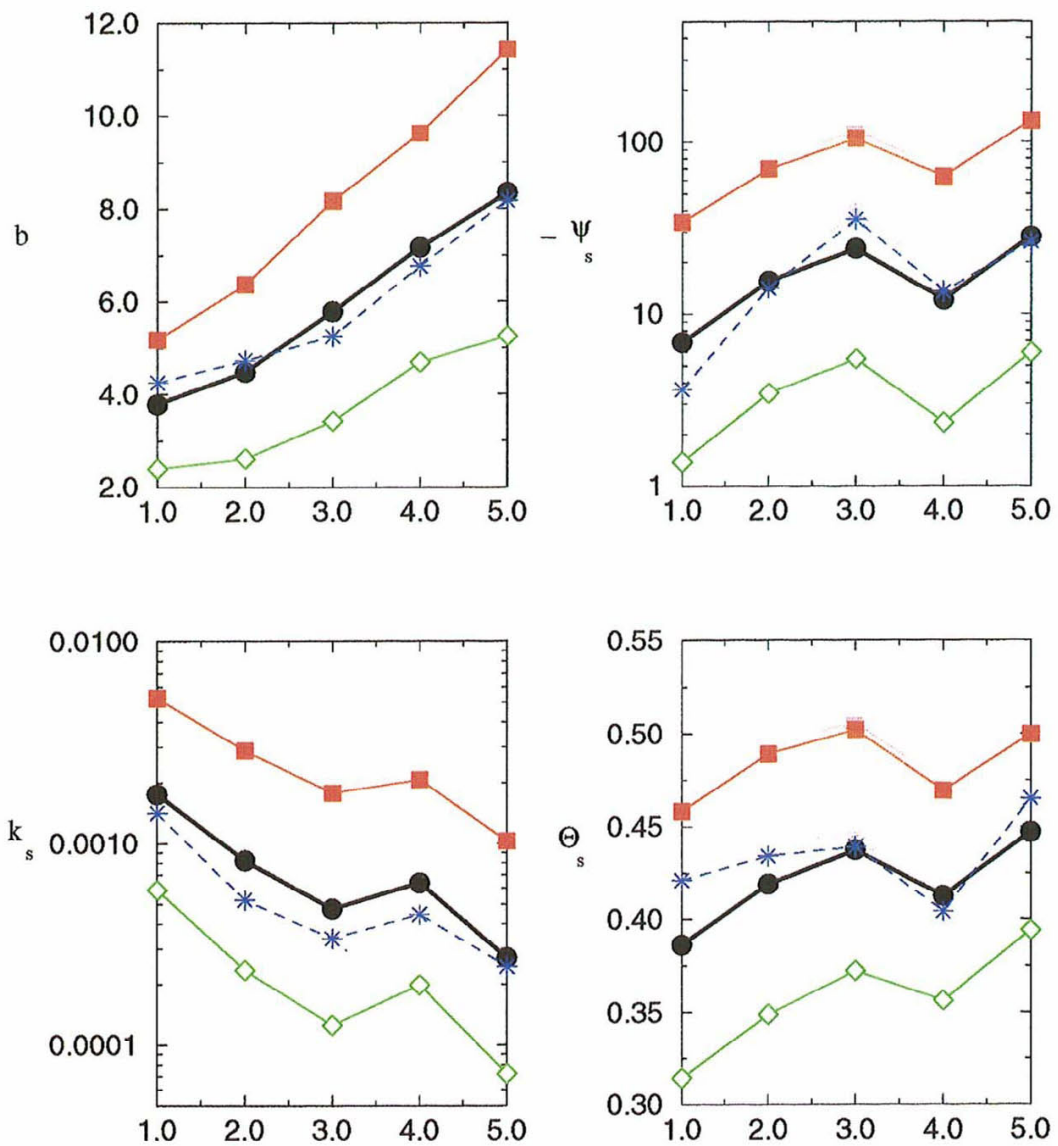

Fig. 1. Soil hydrological parameters from Cosby et al. (1984). The dashed lines with asterisks indicate the parameters specified by GSWP (Table 1), and the lines with circles, squares and diamonds represent the corresponding parameters calculated from Eqs. (2a)-(2c) (Table 2). Parameter units are given in Table 2 .

surface, $\phi$ is the vegetation cover fraction, and $E_{V j}$ and $E_{B j}$ represent evaporation from the vegetated and bare-soil portions of the grid box, respectively, which are functions of soil moisture. The subscript $j$ corresponds to a soil column (or set of soil hydrological parameters), and the soil column probability distribution weights $\left(\alpha_{j}\right)$ are normalized:

$$
\sum_{j=1}^{N_{c}} \alpha_{j}=1
$$

where $N_{c}$ is the total number of soil columns or points along the distribution.

Evapotranspiration is modeled using the "threshold method" (Wetzel and Chang, 1987; Wetzel and Chang, 1988), in which the extraction of soil moisture occurs at the minimum of the stressed (governed soil by moisture), and non-stressed (atmo- spheric potential) rates. The evaporation from the vegetation-covered and bare-soil portions of the grid box are given as

$E_{V j}=\sum_{i=1}^{N} \min \left\{E_{p V}, \max \left[J_{i} E_{T V i, j}\left(\Theta_{i, j}\right), E_{s}\right]\right\}$,

$E_{B j}=\min \left[E_{p B}, E_{T B, j}\left(\Theta_{2, j}\right)\right]$.

Evaporation rates are represented by $E$ : the subscripts $p$ and $T$ represent the atmospheric demand (or potential) limited, and soil moisture supply limited (or threshold) evaporation rates (Wetzel and Chang, 1988), respectively. The subscripts $B$ and $V$ represent the rates for bare-soil and vegetationcovered portions of the grid box. $J$ is the root zone fraction, the index $i$ corresponds to the soil layer, and $N$ is the total number of layers (five layers were 
Table 2. The mean soil parameters are shown in row $j=1$. The parameters representing the +1 standard deviation about the mean are shown in row $j=2$ and the -1 standard deviation are shown in row $j=3$. The regression coefficients are from Cosby et al. (1984). Using the regression equations, only 2 soil input parameters (clay and sand fraction) are required to obtain the 4 soil hydrological parameters from Eqs. (2a)-(2b).

\begin{tabular}{cccrcc}
\hline $\begin{array}{c}\text { GSWP } \\
\text { class }\end{array}$ & $\begin{array}{c}\text { index } \\
j\end{array}$ & $\begin{array}{c}b \\
-\end{array}$ & $\begin{array}{c}k_{s} \\
\left(10^{-6} \mathrm{~m} / \mathrm{s}\right)\end{array}$ & $\begin{array}{c}\psi_{s} \\
(\mathrm{~m})\end{array}$ & $\begin{array}{c}\Theta_{s} \\
\left(\mathrm{~m}^{3} / \mathrm{m}^{3}\right)\end{array}$ \\
\hline 1 & 1 & 3.80 & 17.50 & -0.067 & 0.39 \\
1 & 2 & 5.18 & 52.28 & -0.341 & 0.46 \\
1 & 3 & 2.41 & 5.86 & -0.013 & 0.31 \\
2 & 1 & 4.50 & 8.22 & -0.155 & 0.42 \\
2 & 2 & 6.37 & 28.75 & -0.691 & 0.49 \\
2 & 3 & 2.62 & 2.36 & -0.035 & 0.35 \\
3 & 1 & 5.80 & 4.72 & -0.238 & 0.44 \\
3 & 2 & 8.16 & 17.78 & -1.041 & 0.50 \\
3 & 3 & 3.43 & 1.25 & -0.055 & 0.37 \\
4 & 1 & 7.16 & 6.42 & -0.121 & 0.41 \\
4 & 2 & 9.63 & 20.61 & -0.627 & 0.47 \\
4 & 3 & 4.70 & 2.00 & -0.023 & 0.36 \\
5 & 1 & 8.34 & 2.72 & -0.282 & 0.45 \\
5 & 2 & 11.42 & 10.25 & -1.326 & 0.50 \\
5 & 3 & 5.26 & 0.72 & -0.060 & 0.39 \\
\hline
\end{tabular}

used for the current study, see Wetzel and Boone 1995 for details). $E_{s}$ represents the plant potential rate, which is a function of the plant internal storage reservoir. Water stress is assumed to occur when the unstressed evapotranspiration rate exceeds the corresponding threshold rate from Eqs. (6a) and (6b). Expressions for the potential rates can be found in Wetzel and Boone (1995).

The supply-limited bare-soil evaporation and transpiration rates are functions of soil texture through the four soil hydrological parameters. The threshold rate for the vegetated portion of the surface is

$$
E_{T V i, j}=\rho_{w} \lambda\left[\frac{\psi_{i, j}-\psi_{c}}{R_{P}+\left(\alpha_{R i} / k_{i, j}\right)}\right],
$$

where $R_{P}$ is the plant's internal vascular resistance, $\alpha_{R}$ is a coefficient related to the soil-to-root interface resistance, and $\psi_{c}$ is the critical plant water potential ( -300 to $-200 \mathrm{~m}$ for the current study), below which the plant can no longer extract soil moisture. The latent heat of fusion is given by $\lambda$, and $\rho_{w}$ represents the density of liquid water. $R_{P}$ and $\alpha$ were constant for all soil classes for the current study. Eq. (7) describes the maximum sustainable liquid water flux rate through the plants' interior from the root-soil interface to the leaves (Wetzel and Chang, 1987; Wetzel and Chang, 1988).

The equation for the supply limited bare-soil evaporation was derived from the soil moisture diffusion equation (using a vertically integrated form of Darcy's law) by Wetzel and Chang (1987), and is used in a simplified form in the current version of
PLACE:

$E_{T B j}=$

$\rho_{w} \lambda \frac{-b_{j} k_{s j} \psi_{s j} \Theta_{s j}^{-\left(b_{j}+3\right)} f\left(\Theta_{2, j}\right)}{\left[(1 / 2)\left(b_{j}+3\right)\left(b_{j}+4\right) \Theta_{2, j}{ }^{-\left(b_{j}+2\right)} f\left(\Theta_{2, j}\right)\right]^{1 / 2}}$,

where

$$
\begin{aligned}
& f\left(\Theta_{2, j}\right)=\Theta_{2, j}^{b_{j}+4}-\Theta_{w j}^{b_{j}+3} \\
& {\left[\Theta_{2, j}\left(b_{j}+4\right)-\Theta_{w j}\left(b_{j}+3\right)\right] .}
\end{aligned}
$$

The critical soil water content $\left(\Theta_{w}\right)$ is the point at which evaporation ceases. It is assumed that the soil water in the uppermost thin soil layer has been depleted to it's critical value so that all further extraction is from the layer below.

The governing equation for the time evolution of soil moisture for each soil column is given by the vertically-averaged continuity equation:

$$
\begin{aligned}
& \Delta z_{i} \frac{\partial \Theta_{i, j}}{\partial t}= F_{i, j}-F_{i-1, j} \\
&-\left\{\frac{F}{\rho_{w} \lambda}\left[\phi E_{V i, j}+(1-\phi) E_{B j}\right]-U_{i, j}\right\} \\
&(i=1, N),
\end{aligned}
$$

where $\Delta z_{i}(\mathrm{~m})$ represents the thickness of the model layer $\left(z_{i}-z_{i-1}\right), \Theta_{i, j}\left(\mathrm{~m}^{3} \mathrm{~m}^{-3}\right)$ is the layer-average volumetric water content, $\Delta t$ is the time step, and $F_{i, j}\left(\mathrm{~m} \mathrm{~s}^{-1}\right)$ is the vertical soil moisture flux. The term in braces on the right-hand-side of Eq. (9) represents a soil water sink. Uptake by the plant storage term is represented as $U_{i, j}\left(\mathrm{~m} \mathrm{~s}^{-1}\right)$. The soil 
depth, $z_{i}$, increases downward with increasing in$\operatorname{dex} i$. This equation is solved iteratively for large time steps using the Crank-Nicolson time scheme (see Boone and Wetzel [1996] for details).

The vertical soil moisture flux is evaluated using Darcy's law:

$$
F=-k\left(\frac{\partial \psi}{\partial z}+1\right)
$$

The lower boundary flux (opposite in sign to drainage) is written using Eq. (1b) as

$$
F_{N, j}=-\Omega k_{s j}\left(\Theta_{N, j} / \Theta_{s j}\right)^{2 b_{j}+3} \quad(0 \leq \Omega \leq 1),
$$

where the permeability coefficient at the base of the soil domain $(\Omega)$ is assigned a value of one (so-called free drainage) for the entire globe, in keeping with requirements of the GSWP.

At the surface, the water flux (opposite in sign to infiltration) is written as

$$
F_{0, j}=-\left(R_{t}-R_{0, j}\right)
$$

where $R_{t}$ is the rate at which water reaches the hydrological surface after interception by the snowpack and canopy through fall rate. The surface runoff is calculated following Dümenil and Todini (1992: hereafter referred to as DT92):

$$
\begin{aligned}
& R_{0, j}=R_{t}-\left(\Theta_{s j}-\bar{\Theta}_{j}\right) \frac{\Delta \bar{z}}{\Delta t}+\frac{\delta_{j} \Delta \bar{z} \Theta_{s j}}{\Delta t} \\
& \quad \times\left[\left(1-\frac{\bar{\Theta}_{j}}{\Theta_{s j}}\right)^{1 /(\tau+1)}-\left(\frac{R_{t} \Delta t}{(\tau+1) \Theta_{s j} \Delta \bar{z}}\right)\right]^{\tau+1},
\end{aligned}
$$$$
\left(R_{0, j} \geq 0\right)
$$

where $\bar{\Theta}$ is the average water content over a soil layer of depth $\bar{z}$. This layer thickness encompasses more than one soil layer, and is at least several tenscm thick, as recommended by Liang et al. (1996) $(0.38 \leq \bar{z} \leq 0.75 \mathrm{~m}$ for GSWP $)$.

The parameter $\tau$ controls the magnitude of the effect of sub-grid topography. Subgrid topographic variability implies that the water table will be at, or near the surface for some relatively low-lying subregion within the grid box, so that through-fall over these areas results in immediate runoff. $\tau$ can be calibrated based on catchment data, so that it implicitly represents variability of soils (including texture) and topography. But, as in DT92 (the scheme as used in an Ocean Atmosphere Global Climate Model) and Douville (1998), $\tau$ is calculated based on topographical information only for this study.

For a scale such as that used by GSWP, DT92 suggests a range for this parameter of $0.01 \leq \tau \leq 0.5$, with a typical average value of 0.2 . Values of $\tau$ were computed for this study from the ISLSCP topographical slope dataset, such that the global mean value was 0.2 , and the range used was $0.06 \leq \tau \leq$ 0.46 .

The delta function $\delta_{j}$ is defined as

$$
\delta_{j}= \begin{cases}1 ; & \left(R_{t} \leq R_{c j}\right) \\ 0 ; & \left(R_{t}>R_{c j}\right)\end{cases}
$$

where $R_{c j}$ is determined from

$$
R_{c j}=\frac{(\tau+1) \Delta \bar{z} \Theta_{s j}}{\Delta t}\left(1-\frac{\bar{\Theta}_{j}}{\Theta_{s j}}\right)^{\frac{1}{\tau+1}} .
$$

As the soil layer water content $\bar{\Theta}$ approaches saturation, $R_{c} \rightarrow 0$ so that Eq. (13) represents a buckettype model: through-fall in excess of the grid-box mean water holding capacity of the layer $\bar{z}$ runs off. This is also the case for very high through-fall rates $\left[\delta_{j}=0\right.$ from Eq. (13b)]. For frozen soils, $F_{0, j}$ in PLACE is negligible so that all of the through-fall runs off (i.e., $R_{0, j}=R_{t}$ ).

The total runoff from a grid box at the end of a time step $(\mathrm{m})$ is computed from

$$
\begin{aligned}
R=\sum_{j=1}^{N_{c}} \alpha_{j} & {\left[\Delta t\left(R_{0 j}-F_{N j}\right)\right.} \\
& \left.+\sum_{i=1}^{N} \max \left(0, \Theta_{i, j}-\Theta_{s j}\right) \Delta z_{i}\right] .
\end{aligned}
$$

If the volumetric water content in a soil layer exceeds saturation at the end of the time step, it is considered to be runoff from Eq. (14). In practice, this form of runoff is generally negligible, but is accounted for here to ensure an accurate water balance.

\section{Simulations}

For the GSWP, participant SVATs used atmospheric forcing from the ISLSCP dataset to produce a two-year simulation (1987-1988) for 14637, $1 \times 1$ degree land grid boxes. Parameters needed to describe the vegetation both spatially and temporally (monthly means), and the spatial distribution of the soil hydrological parameters and total soil depth were included within the ISLSCP dataset. SVATs were then to execute the simulation for 1987 up to 10 times in order to achieve an equilibrium state (negligible energy and water imbalances between the start and end of 1987), the so-called model spin-up. The year 1988 was then to be simulated once using the conditions at the end of 1987 as the initial state. SVAT computed quantities related to the energy (e.g., surface fluxes of heat, momentum and surface temperatures), and hydrological budgets (e.g., snow-pack, fluxes of moisture, runoff, and soil water storage) were then reported to the GSWP. 


\subsection{Experiment}

PLACE was used to generate two global simulations using guidelines set up by the GSWP for the current study; a control run $(C)$ and a parameter heterogeneity run $(H)$. The Control $(C)$ run uses a single soil-column configuration in which the mean soil parameter values were used (corresponding to $j=1$ in Table 2). The run considering the hydrological parameter variability $(H)$ is identical to the $C$ run, except it uses three soil columns within each grid box: $j=1$ represents the center of the normal distribution, while the values corresponding to $j=2$, and 3 represent the parameter values at plus one and minus one standard deviations about the mean values, respectively (Table 2). A schematic of the configuration is shown in Fig. 2. The normal distribution weights are 0.46 for the column corresponding to the mean parameter values, while a value of 0.27 was used for the other two columns.

Tests were done (not shown) to determine if sampling the normal distribution at three points was sufficient to accurately model the parameter variability. Using various grid points which were chosen to represent contrasting surface, soil and climate regimes, increased sampling of the distribution of parameter values was done, and those results were then compared to the corresponding grid boxes using the three-column configuration. Some individual grid points do show some relatively minor changes, using a five or more point sampling of the distribution in the range \pm one standard deviation about the mean, but in general, only small changes occur with respect to PLACE simulated annually averaged values of water and energy budget variables. Three columns were used, because of the cost-benefit aspect to this approach, with respect to computer resources as a set of $N \times N_{c}$ prognostic soil moisture variables are required. If examination of the effect of such a method for a smaller time scale is desired, such as a week or less, the distribution should probably be sampled at more than three points.

\subsection{Global annual means}

The globally averaged water budget variables for 1987 are shown in Table 3 for both the $C$ and $H$ simulations. The Precipitation $(P)$, total runoff $(R)$, surface runoff, drainage, root zone water content $\left(W_{r}\right)$ and, evapotranspiration $\left(E / \lambda \rho_{w}\right)$ are in $\mathrm{mm}$. Two nondimensional quantities are also included: the soil wetness, $S W$, and soil wetness index, $S W I$, defined as

$$
\begin{aligned}
S W & =\bar{\Theta}_{r} / \Theta_{s}, \\
S W I & =\left(\bar{\Theta}_{r}-\Theta_{w}\right) /\left(\Theta_{f c}-\Theta_{w}\right),
\end{aligned}
$$

where $\bar{\Theta}_{r}$ represents the layer-average root-zone volumetric water content. $\Theta_{f c}$ is the field capacity volumetric water content calculated from Eq. (1b), assuming a hydraulic conductivity of $0.1-\mathrm{mm} \mathrm{day}^{-1}$

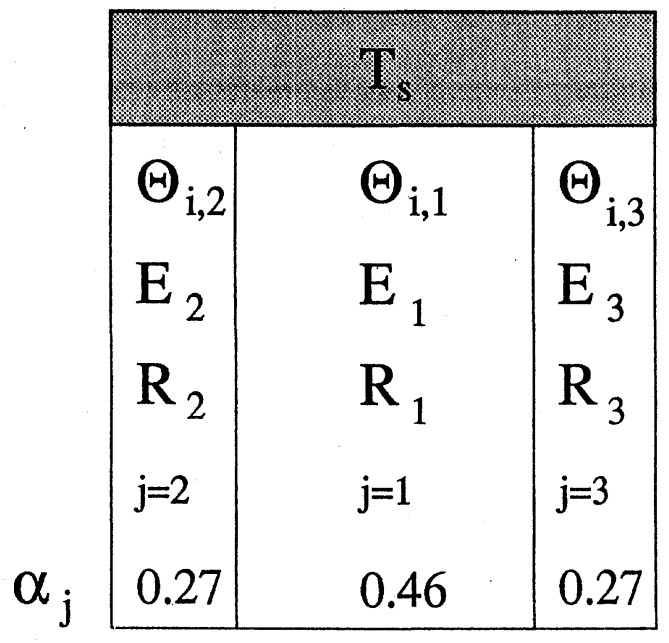

Fig. 2. Diagram of the three-column soil model configuration used by PLACE for the current study. The main components of the water balance are indicated: $\Theta_{i, j}$ is the volumetric water content for each soil layer $i$ in each column $j, R_{j}$ is the total runoff or discharge from each column, and $E_{j}$ represents the extraction of soil moisture from the soil due to evapotranspiration. Column weights (effective area) for each column are given by $\alpha_{j} . T_{s}$ represents the single surface energy budget temperature.

(Wetzel and Chang, 1987). $\Theta_{w}$ is the wilting point water content calculated from Eq. (1a) assuming a critical plant potential of -200 to $-300 \mathrm{~m}$. $S W$ gives a normalized measure of the degree of soil saturation, and it ranges from 0 to 1 . SWI is a normalized soil moisture measure which is useful for describing the efficiency of transpiration by some SVAT schemes. Transpiration is, in general, at the potential rate for values of SWI exceeding unity, whereas it becomes negligible for values of SWI less than or equal to zero. Annually averaged $S W I$ is in the range $0 \leq S W I \leq 1$ for most grid points, although the possible range of the root-zone soil moisture for PLACE is $0.01 \leq \bar{\Theta}_{r} \leq \Theta_{s}$.

Results for 1987 are presented in this study for the first year after model spin-up has occurred at all grid points, implying that the change in soil moisture storage is negligible so that precipitation should be approximately equal to the sum of total runoff and evapotranspiration. Note that the same general trends were observed for 1988, but results are not shown here for the sake of brevity.

The relative difference, $\varepsilon$, was computed for the hydrological variables from

$$
\varepsilon_{Q}=\left(Q_{H}-Q_{C}\right) / Q_{C},
$$

where $Q$ represents a water budget variable. The root mean square (RMS) differences, $R M S_{Q}$, are 
Table 3. Globally averaged components of the water budget. Totals are for the year 1987 in mm. A positive relative difference, or $\varepsilon_{Q}$, indicates that the variable $Q$ increased as a result of the inclusion of soil texture heterogeneity. $P$ represents the precipitation, $R$ represents the total, $R_{0}$ the surface and $-F_{N}$ the drainage runoff. $E / \lambda \rho_{w}$ represents the liquid water equivalent evapotranspiration, $W_{r}$ is the soil water content from the surface to the base of the root zone, $S W$ is the soil wetness (dimensionless), and $S W I$ is the soil wetness index (dimensionless). $Q_{C}$ represents control-run variables, while $Q_{H}$ represents those from the heterogeneity run.

\begin{tabular}{crrrrr}
\hline $\begin{array}{c}\text { Variable } \\
Q\end{array}$ & $\begin{array}{c}Q_{C} \\
(\mathrm{~mm})\end{array}$ & $\begin{array}{c}Q_{H} \\
(\mathrm{~mm})\end{array}$ & $\varepsilon_{Q}$ & $\begin{array}{c}R M S_{Q} \\
(\mathrm{~mm})\end{array}$ & $R M S^{*}{ }_{Q}$ \\
\hline$R_{0}$ & 120.95 & 135.82 & 0.13 & 22.56 & 0.18 \\
$-F_{N}$ & 70.22 & 146.26 & 1.08 & 110.64 & 1.02 \\
$R$ & 191.17 & 282.08 & 0.48 & 128.32 & 0.54 \\
$E / \lambda \rho_{w}$ & 530.99 & 439.72 & -0.17 & 128.21 & 0.26 \\
$W_{r}$ & 186.70 & 215.70 & 0.16 & 3.06 & 0.15 \\
$S W$ & 0.42 & 0.49 & 0.17 & 0.07 & 0.31 \\
$S W I$ & 0.51 & 0.80 & 0.49 & 0.18 & 0.28 \\
$P$ & 720.51 & 720.51 & & & \\
\hline
\end{tabular}

shown in Table 3 for each variable, along with the RMS differences normalized by the mean value for the two simulations, where $R M S_{Q}^{*}=R M S\left(Q_{C}+\right.$ $\left.Q_{H}\right) / 2$.

Surface runoff is increased by $13 \%$ relative to the $C$ run by considering soil hydrological parameter variability, although the actual increase in surface runoff represents only $2 \%$ of the precipitation (i.e., a rather small portion of the overall water budget). The effect is relatively small as the only texture dependent parameter in the surface runoff formulation (Eqs. [13a]-[13c]) is $\Theta_{s}$, which varies linearly for the three soil columns. Evapotranspiration is the most significant component of the water budget as it comprises $74 \%$ and $61 \%$ of the precipitation for the $C$ and $H$ runs, respectively. This corresponds to a $13 \%$ decrease in evapotranspiration relative to precipitation. The relative difference, $\varepsilon_{E}$, as a result of including soil texture heterogeneity is a reduction of evapotranspiration by $17 \%$. Part of this reduced evapotranspiration is related to the increased surface runoff (decreased infiltration), but the surface runoff change represents only approximately $15 \%$ of the absolute change in evapotranspiration. The bulk of the reduction is due to increased drainage (an increased propagation speed of the wetting front), and lower/smeared stressed (soil moisture supply) evapotranspiration rates. Because evaporation in PLACE is governed by the minimum of the atmospheric potential and soil moisture supply rates, overall evapotranspiration is reduced. Note that $E / \lambda \rho_{w}$ also includes direct evaporation from the precipitation interception store, so that the relative difference in plant transpiration and baresoil evaporation (extraction of water from the soil) is actually larger than $17 \%$.

The global-average model drainage, $R_{N}$, more than doubles due to the inclusion of heterogeneity
$\left(\varepsilon_{R_{N}}=1.08\right)$. This is consistent with Wetzel et al. (1996) who stated that heterogeneity in series should increase drainage as the net baseflow should approach that of the most porous constituent soils. The normalized RMS difference is slightly more than half of the mean for the $C$ and $H$ runs, indicating a large spatial variability.

There is a relative increase in root zone soil moisture $\left(W_{r}\right)$ of $16 \%$, which corresponds to a $4 \%$ increase relative to precipitation. The decrease in evapotranspiration induces a net gain in soil moisture in the root zone relative to the sub-root-zone layer, thereby augmenting $S W$ and $S W I$. So, even though $S W I$ is larger for the $H$ run, evapotranspiration is less.

The control global-average runoff ratio, $R_{C} / P$, is 0.27 , while the value for the heterogeneity case, $R_{H} / P$, is 0.39 . The global climatological runoff ratio is generally accepted to be 0.31 to 0.38 , so that the PLACE runoff ratio has improved slightly, but has changed signs with respect to the error difference. Global surface runoff has been estimated to range from roughly $50 \%$ of total runoff (L'vovich, 1979) to $24 \%$ (Probst and Sigha, 1989). This range in observations is rather large, so there is a great deal of uncertainty related to this ratio. The ratio from $C$ is $63 \%$, while the value for the $H$ run is $48 \%$. Heterogeneity has changed the partitioning of the total runoff, primarily by augmenting baseflow.

\subsection{Relation to precipitation}

It is interesting to compare the results to the climatological forcing variables. Precipitation has the most direct effect on the changes in the water budget arising from soil hydrological parameter variability. The 14637 grid-box annual precipitation totals for 1987 were ordered from lowest to highest, and then five precipitation bins were created such that an equal amount of precipitation fell into each bin. 
Table 4. The relative error, $\varepsilon_{Q}$, as a function of precipitation bin $n$ for the components of the water budget. The total precipitation for each bin is constant, but the corresponding area of the globe over which it falls $\left(A_{n}\right)$ decreases with increasing bin number (relatively wetter regions).

\begin{tabular}{crrrrr}
\hline $\mathrm{Q}$ & 1 & 2 & 3 & 4 & 5 \\
\hline$P_{n}$ & 0.20 & 0.20 & 0.20 & 0.20 & 0.20 \\
$A_{n}$ & 0.53 & 0.20 & 0.12 & 0.09 & 0.06 \\
$P_{n} / A_{n}$ & 0.38 & 1.00 & 1.67 & 2.22 & 3.33 \\
$R_{0}$ & 0.07 & 0.14 & 0.16 & 0.16 & 0.11 \\
$-F_{N}$ & 4.98 & 3.36 & 1.58 & 0.87 & 0.37 \\
$R$ & 0.43 & 0.74 & 0.67 & 0.49 & 0.26 \\
$E / \lambda \rho_{w}$ & -0.13 & -0.18 & -0.19 & -0.18 & -0.17 \\
$W_{r}$ & 0.21 & 0.19 & 0.13 & 0.08 & 0.05 \\
\hline
\end{tabular}

Table 5. The relative difference for the water budget components for various river basins defined using the TRIP dataset (Oki and Sud, 1998). The first 10 basins listed represent the 10 largest in the world by area: the latter 8 are important from a socio-economic standpoint. The ratio of the average basin precipitation to the global average is represented by $P_{b} . A_{b}$ represents the area of each basin. The differences between the control and heterogeneity runs are given for total runoff, $\varepsilon_{R}$, surface runoff, $\varepsilon_{R_{0}}$, evapotranspiration, $\varepsilon_{E}$, and root zone soil moisture, $\varepsilon_{W_{r}}$.

\begin{tabular}{rlcccccc}
\hline ID & Name & $\begin{array}{c}A_{b} \\
\left(10^{6} \mathrm{~km}^{2}\right)\end{array}$ & $\begin{array}{c}P_{b} \\
-\end{array}$ & $\begin{array}{c}\varepsilon_{R} \\
-\end{array}$ & $\begin{array}{c}\varepsilon_{R_{0}} \\
\varepsilon_{E}\end{array}$ & $\varepsilon_{W_{r}}$ \\
\hline 1 & Amazon & 6.14 & 2.68 & 0.25 & 0.15 & -0.10 & 0.04 \\
2 & Congo & 3.73 & 1.85 & 0.47 & 0.13 & -0.10 & 0.08 \\
3 & Mississippi & 3.25 & 0.96 & 0.72 & 0.22 & -0.12 & 0.21 \\
4 & Parana & 2.97 & 1.81 & 0.71 & 0.26 & -0.22 & 0.11 \\
5 & Ob & 3.00 & 0.63 & 0.08 & 0.04 & -0.03 & 0.21 \\
6 & Nile & 2.96 & 0.83 & 1.03 & 0.29 & -0.19 & 0.18 \\
7 & Yenisey & 2.61 & 0.56 & 0.15 & 0.05 & -0.07 & 0.23 \\
8 & Lena & 2.35 & 0.46 & 0.16 & 0.05 & -0.07 & 0.24 \\
9 & Niger & 2.11 & 0.79 & 0.54 & 0.13 & -0.19 & 0.09 \\
10 & Amur & 1.87 & 0.78 & 0.59 & 0.16 & -0.08 & 0.20 \\
11 & Orange & 1.00 & 0.49 & 2.05 & 0.27 & -0.23 & 0.23 \\
12 & Indus & 0.97 & 0.44 & 0.59 & 0.11 & -0.18 & 0.22 \\
13 & St. Lawrence & 1.11 & 1.07 & 0.25 & 0.07 & -0.05 & 0.23 \\
14 & Yellow & 0.78 & 0.61 & 1.19 & 0.28 & -0.22 & 0.24 \\
15 & Euphrates & 0.76 & 0.36 & 0.54 & 0.03 & -0.28 & 0.11 \\
16 & Rio Grande & 0.61 & 0.54 & 1.35 & 0.41 & -0.17 & 0.30 \\
17 & Colorado TX & 0.12 & 0.99 & 1.43 & 0.40 & -0.22 & 0.15 \\
18 & Rhone & 0.10 & 1.40 & 0.31 & 0.05 & -0.26 & 0.06 \\
\hline
\end{tabular}

The resulting average precipitation rates for each bin are shown in Table 4: the average precipitation rate (and total annual precipitation at each grid point within each bin) increases as a function of increasing bin number. The area of each bin, $A_{n}$, relative to the total area of all the grid points modeled is also shown.

The $\varepsilon$ and $R M S^{*}$ values for the water budget variables as a function of precipitation bin are also shown in Table 4. Surface runoff relative differences increase with increasing precipitation rate, but drop slightly for the most moist bin (5). This occurs for two reasons: 1) the areas receiving the most precipitation tend to have the most dense vegetation canopies which dampen the effect of soil heterogeneity (large amounts of evapotranspiration can result from interception for example), and 2) for large rain rates Eq. (13a) collapses into a linear equation in $\Theta_{s}$ $\left(\delta_{j}=0\right)$, so that the multi-column grid box average $R_{0 j}$ is not different from the single column value.

Relative differences in drainage runoff dramatically increase with decreasing bin numbers. This results because small absolute changes in runoff for dry regions can cause large relative changes. But this is an important result as large relative increases (even if small in the absolute sense) in runoff can trigger flooding in relatively dry regions. Evapotranspiration, in contrast, does not change much across 
the 5 bins, although the relative difference is slightly less for the driest bin. The relative difference in root zone soil moisture is largest for the soils with the least amount of root zone water storage (lowest bin numbers).

Evapotranspiration is consistently reduced in PLACE due to soil texture heterogeneity, and it does not seem to be closely related to precipitation (except possibly for the driest regions). In contrast, runoff (especially drainage) is much more dependent on the precipitation regime.

\subsection{River basin scale}

Because of the large impact of soil heterogeneity on the runoff, it is interesting to examine the water budget at a river basin scale. This is important as large increases in runoff in the headwater regions of a basin can then propagate downstream into regions which actually show little sensitivity to runoff on the grid-box scale. Basins were defined for this analysis using the Total Runoff Integrating Pathways (TRIP) basin dataset (Oki and Sud, 1998). The relative differences $(\varepsilon)$ for the total runoff, surface runoff, evapotranspiration and root zone water content are shown in Table 5 . The basins are ranked by surface area, and the ten largest basins are listed first, then eight additional basins (somewhat arbitrarily selected) which are of socio-economic importance follow. The corresponding ratio, $P_{r}$, of the basin average precipitation to the global average is shown. The runoff ratio for both the $C$ (dark shading), and $H$ runs (light shading) are shown for each of the 18 basins in Fig. 3.

The river basins which show the least amount of effect due to texture heterogeneity are typically high latitude basins, such as the Lena, Ob, Yenisey and St. Lawrence. With the exception of the St. Lawrence basin, these basins are relatively dry and cold (considerable freezing depths in PLACE), so that the relative change in evapotranspiration and surface runoff are small. Although the St. Lawrence receives relatively high precipitation rates, PLACE limits the effect of texture variability primarily due to soil freezing (a good deal of snow melt runs off as the soil thaws in Spring). Another region with a small relative effect on total runoff, but a totally different climate is the Amazon. A large amount of precipitation results in relatively moist soils, so the relative effect of drainage increases are small. Also, a good deal of intercepted precipitation is evaporated before reaching the soil. But the small relative effect in basins such as the Amazon (compared to other basins) is still important as it causes a large increase in the actual quantity of water which runs off. The increase in basin-average total runoff is approximately $150(\mathrm{~mm} / \mathrm{yr})$.

River basins with the largest relative difference in runoff are relatively warm and dry, such as the

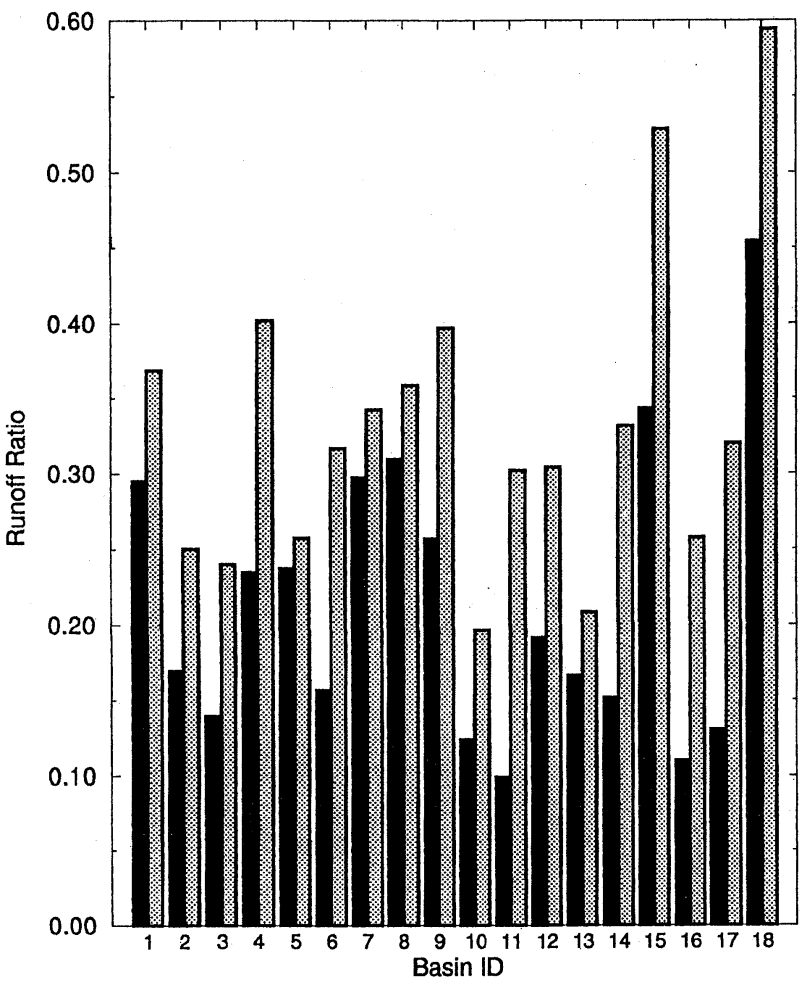

Fig. 3. Total annual runoff ratio, $R / P(\%)$, for 1987 for the the control and heterogeneity simulations for 18 river basins defined using the TRIP dataset (Oki and Sud, 1998). Dark shaded bars correspond to the control, $C$, run, while light shaded bars correspond to the heterogeneity, $H$, run.

Colorado, Rio Grande, Orange, Yellow and Nile. Relative differences are approximately $100 \%$ for the Yellow, and Nile basins (Table 5). In contrast, the Parana river basin receives a similar amount of precipitation per unit area as the Congo (which is very wet), and still has a relatively large increase in runoff. The Mississippi basin receives an amount of precipitation approaching the global mean value (about $1 / 2$ of that of the Parana), yet it has a similar large relative difference in runoff as the Parana. The reason for the relatively large effect for these relatively wet (precipitation) basins are related to the spatial and temporal variations in atmospheric forcing, and vegetation cover with respect to the underlying heterogeneous soil. So while some generalizations are possible to explain the effect of parameter variability (texture variability), the effect varies with respect to PLACE through many complex interactions.

\subsection{Grid box scale}

Grid box annual average fields are shown in Fig. 4. The ISLSCP/forcing precipitation is shown in Panel a for reference. The grid-box annual mean difference in runoff ratio $(H-C)$ for 1987 is shown in Panel 

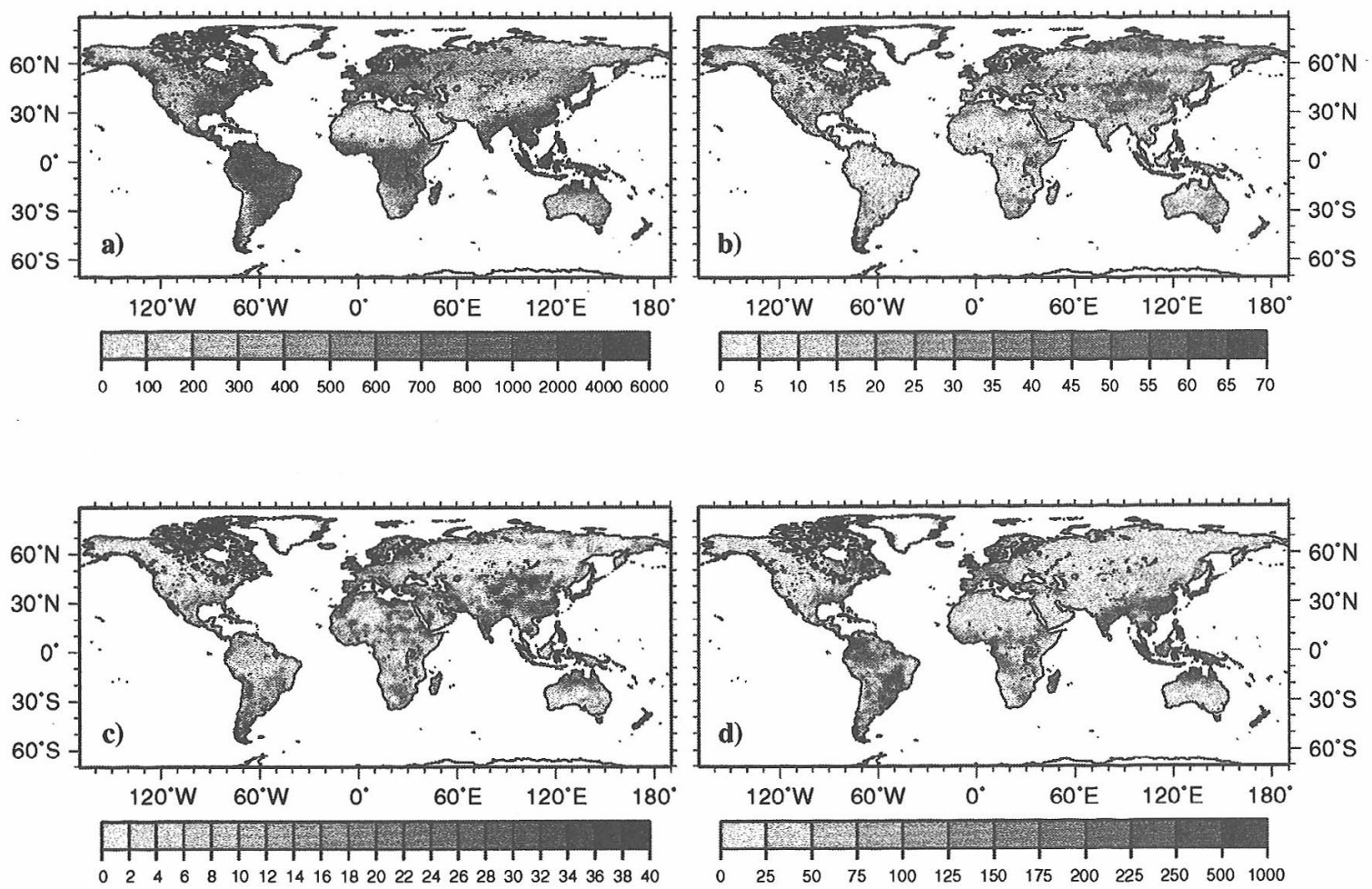

Fig. 4. Grid point differences between the $C$ and $H$ experiments (due to the inclusion of soil parameter variability). Variables are calculated from the annual averages for 1987. Panel a: ISLSCP precipitation. Panel b: the relative increase in root-zone soil moisture (\%). Panel $\mathrm{c}$ : the percent change (absolute increase) in runoff ratio (runoff/precipitation). Panel d: absolute increase in total runoff $(\mathrm{mm})$.

c. Relatively dry regions (i.e., with low precipitation) have large increases in runoff ratio: northern Canada, Tibet plateau, Gobi desert, southwestern Asia, northwestern Africa, and the mountainous regions of southern South America. There are also some moderately wet regions that have a significant impact: the south-eastern United States, northern Quebec, India, south-eastern China, and northern Australia. Factors such as vegetation and other atmospheric forcing variables come into play; precipitation is not the only important factor with respect to changes in runoff ratio.

The relative changes in soil moisture are shown in Panel b. The soil moisture was increased more consistently for the entire globe, so that relative changes are largest for the driest soils. A notable exception to this is over northern Africa, which remained relatively dry for both simulations. The total runoff difference is shown in Panel $d$. The changes in total runoff are largest for the wettest regions in general. Central Africa, portions of interior Brazil, and Thailand are notable exceptions. For these regions, significant vegetation canopies diminish the change in runoff somewhat due to the fact that a large portion of the incident precipitation is evaporated from interception storage.

\section{Summary}

A statistical approach is used to incorporate soil hydrological parameter variability into the PLACE model by assuming subgrid heterogeneity can be modeled using multiple parallel homogeneous soil columns within a single grid box. A single energy balance equation is preserved which reduces the number of surface parameters relative to a multiple surface tile approach. Simple regression relationships are used, which relate the grid-box average soil texture to the soil hydrological parameters and their statistical moments. No ancillary information is needed to calculate the model parameters. For the present study, three such columns were used within each grid box.

The inclusion of subgrid soil hydrological parameter variability in PLACE (related to soil texture heterogeneity) increases surface runoff, especially for regions with relatively larger annual precipitation totals. Evapotranspiration is reduced by a similar magnitude over most of the globe, but is not highly spatially correlated with precipitation. The increased surface runoff is responsible for a minor decrease in evapotranspiration, but the bulk of this decrease is due to the lower upper limit for the water stressed relations for bare-soil evaporation and tran- 
spiration. Like the surface runoff, drainage is also increased. In contrast to surface runoff increases though, relative differences in drainage are largest for the driest regions of the globe, as hydraulic conductivity is increased significantly, and drainage occurs over a larger range of grid-box average soil moisture. Texture heterogeneity also tends to make the driest soils more moist in PLACE, while changing the wettest soils less in a relative sense. The results provide evidence that an effect on a simulated climate is possible through changes in the partitioning of net radiation between sensible and latent heat fluxes into the atmosphere. It is important to determine whether the climate simulated by an atmospheric model is sensitive to these processes.

Consideration of the inherent nonlinearity in the CH78 model (used by many SVAT schemes) parameters considerably change the PLACE simulated water budget. The effect of texture heterogeneity on evapotranspiration, with respect to other SVAT schemes, will depend upon a particular model's formulation for soil water stressed rates, (these methods vary widely for SVATs in general). Some schemes use coefficients which are linear with respect to soil moisture (where the effects of soil parameter variability would most likely be minimized), while many schemes use relations which are nonlinearly related to soil moisture through use of the soil water potential. PLACE supply limited transpiration rates are derived using the classical potentialresistance model, and the bare-soil rate is derived from a vertical integration of Darcy's law. Some extrapolation of the heterogeneity effects outlined here to other models with similar physics is therefore possible. At the very least, any model using the CH78 formulations could have an impact from incorporation of parameter variability on vertical soil moisture fluxes (infiltration, diffusion, runoff and drainage), and then possibly on evapotranspiration as a second order effect.

Illustration of the effect of soil parameter variability, which is linked to texture heterogeneity, on annual global scale water budgets is accomplished by the inclusion of a conceptually simple method in the PLACE SVAT scheme, using the somewhat limited global data from the GSWP, to model soil texture variability. A more quantitative application of this method could be made if data describing subgrid variability of texture, or measured hydrological parameters, within a grid box were available. It is suggested that this information could be included in future global datasets, such as ISLSCP initiative II.

\section{Acknowledgments}

The authors are grateful to Dr. Paul Dirmeyer for his hard work and accessibility, and to three anonymous reviewers who made many helpful suggestions for improving this manuscript. Also, special thanks to Dr. Taikan Oki who has made his TRIP dataset available to the public via the internet. Finally, thanks to Dr. Joël Noilhan for allowing the completion of this work at Météo-France.

\section{Appendix List of Symbols}

$E$ evapotranspiration from the surface/plants/soil

$E_{V} \quad$ evaporation from the vegetated portion of the surface

$E_{B}$ evaporation from the bare-soil portion of the surface

$E_{D} \quad$ evaporation of intercepted water or dew

$E_{s} \quad$ evaporation from plant storage

$E_{T B}$ threshold evaporation rate for bare-soil

$E_{T V}$ threshold evaporation rate for vegetation

$E_{p B} \quad$ potential evaporation rate for bare-soil

$E_{p V} \quad$ potential evaporation rate for vegetation

$F \quad$ grid inter-facial soil water flux

F fractional coverage of water in the interception reservoir

$F_{N} \quad$ water drainage through the base of the model

$G$ ground heat flux

$H$ sensible heat flux

$J$ root fraction for each soil layer

$N$ total number of soil hydrological model layers

$N_{c} \quad$ total number of soil columns

$P$ precipitation

$Q_{C} \quad$ variable from the control simulation

$Q_{H} \quad$ variable from the soil texture heterogeneity simulation

$R$ total soil water runoff

$R_{c}$ critical precipitation rate

$R_{n}$ net radiation flux

$R_{p}$ plant internal vascular resistance

$R_{t}$ rate water reaches the soil hydrological model surface 
$R_{0} \quad$ surface water runoff

$S_{m}$ energy used to melt snow cover

$S W$ soil wetness

$S W I$ soil wetness index

$T_{s}$ surface temperature

$U$ soil moisture uptake for plant storage

$W_{r}$ soil water content (depth)

$b$ empirical constant which is a function of soil type

$b_{m}$ heat capacity of the surface layer

$g$ parameter mean values from regression equations

$i \quad$ vertical soil index

j soil column index

$k \quad$ soil hydraulic conductivity

$k_{s} \quad$ saturation hydraulic conductivity

$z$ vertical coordinate from the soil surface down

$\Delta t \quad$ model time step

$\Delta z \quad$ soil model layer thickness

$\Theta \quad$ volumetric water content of the soil

$\Theta_{f c} \quad$ field capacity volumetric water content

$\bar{\Theta}_{r}$ mean root zone volumetric water content

$\Theta_{s} \quad$ saturation volumetric water content or soil porosity

$\Theta_{w} \quad$ wilting point volumetric water content

$\Omega \quad$ coefficient for permeability of lower boundary of hydrology model

$\alpha \quad$ soil column weight

$\alpha_{R} \quad$ soil-to-root interface resistance coefficient

$\beta$ regression coefficients for calculating parameter means

$\chi$ clay, silt or sand fraction of the soil

$\epsilon_{Q}$ relative error measure for variable defined as $Q$

$\gamma$ regression coefficients for parameter standard deviation

$\lambda$ latent heat of vaporization for water $\phi \quad$ fractional coverage of surface by transpiring vegetation

$\psi \quad$ soil water matric potential

$\psi_{c} \quad$ critical plant water matric potential

$\psi_{s} \quad$ saturation water matric potential

$\sigma$ one standard deviation about parameter mean

$\tau \quad$ single tunable surface runoff parameter

$\rho_{w} \quad$ density of liquid water

\section{References}

Abramopoulos, F., C. Rosenzweig and B. Choudhury, 1988: Improved ground hydrology calculations for Global Climate Models (GCMs): Soil water movement and evapotranspiration. J. Climate, 1, 921941.

Avissar, R. and R.A. Pielke, 1989: A parameterization of heterogeneous land surfaces for atmospheric numerical models and its impact on regional meteorology. Mon. Wea. Rev., 117, 2113-2136.

Bonan, G.B., 1996: A land surface model (LSM version 1.0) for ecological, hydrological, and atmospheric studies: technical description and user's guide. National Center for Atmospheric Research, Boulder, CO, Tech. Note TN-417+STR, 150pp.

Boone, A. and P.J. Wetzel, 1995: Issues related to low resolution modeling of soil moisture: experience with the PLACE model. Global and Plan. Change, 13, 161-181.

Chen, F. and R. Avissar, 1994: The impact of landsurface wetness heterogeneity in mesoscale heat fluxes. J. Appl. Meteor., 33, 1323-1340.

Chen, T.H., A. Henderson-Sellers, P.C.D. Milly, A.J. Pitman, A.C.M. Beljaars, J. Polcher, F. Abramopoulos, A. Boone, S. Chang, F. Chen, Y. Dai, C.E. Desborough, R.E. Dickinson, L. Duemenil, M. Ek, J.R. Garratt, N. Gedney, Y.M. Gusev, J. Kim, R. Koster, E. Kowalczyk, K. Laval, J. Lean, D. Lettenmaier, X. Liang, J.-F. Mahfouf, H.-T. Mengelkamp, K. Mitchell, O.N. Nasonova, J. Noilhan, A. Robock, C. Rosenweig, J. Schaake, C.A. Schlosser, J.-P. Schulz, Y. Shao, A.B. Shmakin, D.L. Verseghy, P. Wetzel, E.F. Wood, Y. Xue, Z.-L. Yang and Q. Zeng, 1997: Cabauw experimental results from the project for intercomparison of landsurface schemes (PILPS). $J$. Climate, 10, 1194-1215.

Clark, C. and R. Arritt, 1995: Numerical simulations of the effect of soil moisture and vegetation cover on the development of deep convection. J. Appl. Meteor., 34, 2029-2045.

Clapp, R. and G. Hornberger, 1978: Empirical equations for some soil hydraulic properties, Water Resour. Res., 14, 601-604.

Cosby, B.J., G.M. Hornberger, R.B. Clapp and T.R. Ginn, 1984: A statistical exploration of the relationships of soil moisture characteristics to the physical properties of soils, Water Resour. Res., 20, 682-690. 
Deardorff, J.W., 1977: A parameterization of ground surface moisture content for use in atmospheric prediction models. J. Appl. Meteor., 16, 1182-1185.

Desborough, C.E., 1997: The impact of root-weighting on the response of transpiration to moisture stress in a land surface scheme. Mon. Wea. Rev., 125, 19201930.

Desborough, C.E., 1998: Evaporative surface stress in land-surface models: impact of inter-model parameterization differences. Ph.D. dissertation, Macquarie University, Sydney, Australia.

Desborough, C.E., A.J. Pitman and P. Irannejad, 1996: Analysis of the relationship between the bare soil evaporation and soil moisture simulated by 13 land surface schemes for a simple non-vegetated site. Global and Plan. Change, 13, 47-56.

Dickinson, R.E., A. Henderson-Sellers and P.J. Kennedy, 1993: Biosphere-Atmos-phere Transfer Scheme (BATS) Version 1e as coupled to the NCAR Community

Climate Model, National Center for Atmospheric Research, Boulder, CO, Tech. Note TN-387+STR, 72pp.

Dirmeyer, P.A., 1997: The Global Soil Wetness Project, GEWEX News, 7, 3-6.

Douville, H., 1998: Validation and sensitivity of the global hydrologic budget in stand alone simulations with the ISBA land-surface scheme. Clim. Dyn., 14, 151-171.

Dümenil, H. and E. Todini, 1992: A rainfall-runoff scheme for use in the Hamburg climate model. Adv. Theor. Hydrol., 9, 129-157.

Gao, W., 1995: Parameterization of subgrid-scale land surface fluxes with emphasis on distributing mean atmospheric forcing and satellite-derived vegetation index. J. Geophys. Res., 100(14), 305-317.

Henderson-Sellers, A., Z.-L. Yang and R.E. Dickinson, 1993: The project for intercomparison of landsurface parameterization schemes. Bull. Amer. Meteor. Soc., 74, 1335-1349.

Kabat, P., R.W.A. Hutjes and R.A. Feddes, 1997: The scaling characteristics of soil parameters: From plot scale heterogeneity to subgrid parameterization. $J$. Hydrol., 190, 363-396.

Koster, R.D. and M.J. Suarez, 1992: Modeling of the land surface boundary in climate models as a composite of independent vegetation stands. J. Geophys. Res., 97, 2697-2715.

Koster, R.D. and M.J. Suarez, 1996: Energy and water balance calculations in the Mosaic LSM. Technical Report Series on Global Modeling and Data Assimilation. NASA Tech. Memo. 104606, 9, 58pp.

Koster, R.D. and P.C.D. Milly, 1997: The interplay between transpiration and runoff formulations in land surface schemes used with atmospheric models. $J$. Climate, 7, 1578-1591.

Liang, X., E. Wood and D. Lettenmaier, 1996: Surface soil moisture parameterization of the VIC-2L model: Evaluation and modification. Global and Plan. Change, 13, 195-206.

L'vovich, M.I., 1979: World Water Resources and Their Future, American Geophysical Union, Washington DC, 415pp.
Mahfouf, J.-F., C. Ciret, A. Ducharne, P. Irannejad J. Noilhan, Y. Shao, P. Thorton, Y. Xue and Z.-L. Yang, 1996: Analysis of transpiration results from the RICE and PILPS workshop. Global and Plan. Change, 13, 73-88.

Mahrt, L. and H. Pan, 1984: A two-layer model of soil hydrology. Bound.-Layer Meteor., 29, 1-20.

Meeson, B.W., F.E. Corprew, J.M.P. McManus, D.M. Meyers, J.W. Closs, K.-J. Sun, D.J. Sunday and P.J. Sellers, 1995: ISLSCP Initiative IGlobal Data Sets for Land-Atmosphere Models, 1987-1988. Volumes 1-5. Published on CD by NASA (USA_NASA_ GDAAC_ISLSCP_001 USA_NASA_GDAAC_ISLSCP_005)

Mihailovic, D.T., 1996: Description of a land-air parameterization scheme (LAPS). Global and Plan. Change, 13, 207-215.

Noilhan, J. and S. Planton, 1989: A simple parameterization of land surface processes for meteorological models. Mon. Wea. Rev., 117, 536-549.

Oki, T. and Y.C. Sud, 1998: Design of Total Runoff Integrating Pathways (TRIP)- A global river channel network. Earth Interactions, 2, [Available on-line at http://Earth-Interactions.org], 31pp.

Pielke, R.A., G. Dalu, J.S. Snook, T.J. Lee and T.G.F. Kittel, 1991: Nonlinear influence of mesoscale land use on weather and climate. J. Climate, 4, 10531069.

Pitman, A.J., Z.-L. Yang, J.G. Cogley and A. Henderson-Sellers, 1991: Description of Bare Essentials of Surface Transfer for the Bureau of Meteorology research Centre AGCM, BMRC research report No. 32, Melbourne, Australia, 132pp.

Pitman, A.J., A. Henderson-Sellers, F. Abramopoulos, R. Avvisar, G. Bonan, A. Boone, J.G. Cogley, R.E. Dickinson, M. Ek, D. Entekhabi, J. Famiglietti, J.R. Garratt, M. Frech, A. Hahmann, R. Koster, E. Kowalczyk, K. Laval, L. Lean, T.J. Lee, D. Lettenmaier, X. Liang, J-F. Mahfouf, L. Mahrt, C. Milly, K. Mitchell, N. de Noblet, J. Noilhan, H. Pan, R. Pielke, A. Robock, C. Rosenzwig, S.W. Running, A. Schlosser, R. Scott, M. Suarez, S. Thompson, D. Verseghy, P. Wetzel, E. Wood, Y. Xue, Z-L. Yang, L. Zhang, 1993: Results from the off-line Control Simulation Phase of the Project for Intercomparison of Landsurface Parameterization Schemes (PILPS), GEWEX Tech. Note, IGPO Publ. Series, 7, 47pp.

Probst, J.-L. and N. Sigha, 1989: Estimation de l'écoulement superficiel et de sa charge en suspension sur quelques grands bassins fluviaux du monde, C. R. Acad. Sci. Paris, 309, (II), 357-363.

Quinn, P.F. and K.J. Beven, 1993: Spatial and temporal predictions of soil moisture dynamics, runoff, variable source areas and evapotranspiration for Plynlimon, mid-Whales. Hydrological Processes, 7, 425448.

Sellers, P.J., Y. Mintz, Y.C. Sud and A. Dalcher, 1986 : A simple biosphere model $(\mathrm{SiB})$ for use within general circulation models. J. Atmos. Sci., 43, 505-531.

Sellers, P.J., B.W. Meeson, J. Closs, J. Collatz, F. Corprew, D. Dazlich, F.G. Hall, Y. Kerr, R. Koster, S. Los, K. Mitchell, J. McManus, D. Meyers, K.-J. Sun and P. Try, 1995: An overview of the ISLSCP Initia- 
tive I Global Data Sets for Land-Atmosphere models, 1987-1988. Volumes 1-5. Published on CD by NASA. Volume 1: USA_NASA_GDAAC_ISLSCP_001, OVERVIEW.DOC.

Seth, A., F. Giorgi and R.E. Dickinson, 1994: Simulating fluxes from heterogeneous land surfaces: explicit subgrid method employing the biosphere-atmosphere transfer scheme (BATS), J. Geophys. Res., 99(18), 651-677.

Shao, Y. and A. Henderson-Sellers, 1996: Validation of soil moisture simulation in landsurface parameterization schemes with HAPEX data. Global and Plan. Change, 13, 11-46.

Stieglitz, M., D. Rind, J. Famiglietti, C. Rosenzweig, 1997: An efficient approach to modeling the topographic control of surface hydrology for regional and global climate modeling. J. Climate, 10, 118-137.

Verseghy, D.L., 1991: CLASS - A Canadian land surface scheme for GCMs. I. Soil Model. Int. J. Climatol., 11, 111-133.

Viterbo, P. and A.C.M. Beljaars, 1995: An improved land surface parameterization scheme in the ECMWF model and its validation. J. Climate, 8 , 2716-2748.

Wetzel and J.-T. Chang, 1987: Concerning the relationship between evapotranspiration and soil moisture. J. Climate Appl. Meteor., 26, 18-27.

Wetzel and J.-T. Chang, 1988: Evapotranspiration from nonuniform surfaces: A first approach for short-term numerical weather prediction. Mon. Wea. Rev., 116, 600-621.

Wetzel and A. Boone, 1995: A parameterization for Land- Atmosphere-Cloud-Exchange (PLACE): Documentation and testing of a detailed process model of the partly cloudy boundary layer over heterogeneous land. J. Climate, 8, 1810-1837.

Wetzel X. Liang, P. Irannejad, A. Boone, J. Noilhan, Y. Shao, C. Skelly, Y. Xue and Z.L. Yang, 1995: Modeling vadose zone liquid water fluxes: Infiltration, runoff, drainage, interflow. Global and Plan. Change, 13, 57-71.

Wood, E., D. Lettenmaier and V. Zartarian, 1992: A land-surface hydrology parameterization with subgrid variability for general circulation models. $J$. Geophys. Res., 97, 2717-2728.

Wood, E., D. Lettenmaier, X. Liang, D. Lohmann, A. Boone, S. Chang, F. Chen, Y. Dai, C. Desborough, Q. Duan, M. Ek, Y. Gusev, F. Habets, P. Irannejad, R. Koster, O. Nasanova, J. Noilhan, J. Schaake, A. Schlosser, Y. Shao, A. Shmakin, D. Verseghy, J. Wang, K. Warrach, P. Wetzel, Y. Xue, Z.-L. Yang and Q. Zeng, 1998: The Project for Intercomparison of Land-Surface Parameterization Schemes (PILPS) Phase-2c Red-Arkansas River Basin experiment: 3. experiment description and summary intercomparisons. Global and Plan. Change, 19, 115-136. 


\title{
グリッド內の土壇特性の変動をモデル化するための 大気気候モデル用のシンプルなスキーム
}

\author{
Aaron Boone \\ (フランス気象庁国家気象研究所) \\ Peter J. Wetzel \\ （アメリカ航空宇宙局ゴッダード宇宙飛行センター）
}

全球大気気候モデルに典型的な空間スケールでは、蒸発散、土壤水分、そして流量といった水収支要素 は、主に土畩水分の非一様性のために、格子内で非線型的に変動しうる。この変動のかなりの部分は格子 内における土䁃特性の変動に起因している。こうしたスケールでは、土壤水文学的特性を特徵づけるパラ メータの変動を考慮することが適切である。土䁃水分パラメータの変動を特徴づけることの可能な、気候 モデル用に扱いやすい簡潔な手法を提案した。それは、同一の土畩/植生境界面の下に、水平方向には相 互作用しないいくつかの土壌カラムを配置する手法である。各土壌カラムごとに定めねばならない水文学 的パラメータの平均値と統計的積率は、格子平均の土壇特性 (砂と粘土質の割合) から単純な回帰関係に よって定められるようにした。取得可能な格子内の土壤特性の変動情報はグローバルには限られているこ とからこの簡潔な手法を用いることにした。全球土畩水分プロジェクト (GSWP) の数值実験の枠組みで、 土壤特性の非一様性を考慮してグローバルな土壤水分を推定するのに PLACE モデルを用いた。格子平均 蒸発散量 (地表面エネルギー収支算定に利用)、土壤水分量、そして流量は 3 つの土壤カラムの重みつき平 均で表現された。非均一性の考慮によって主要な水収支構成要素に大きな影響が現れた。各格子点内の土 壤特性が均一であると仮定した標準計算に比べて全球平均の蒸発量は $17 \%$ 減少して全球流出量は $48 \%$ 増 加した。全球平均の流出率は $12 \%$ 増加した。土畩水分は $19 \%$ 増加して、土畩水分指標は $49 \%$ 増加した。 今後のグローバルな地表面データセットには、格子内の非均一性をいかにモデル化するかについて検討す るために、格子内の土壤の非一様性に関する情報が含まれていることが望ましい。 